\title{
Assessment of yield loss of mustard due to Alternaria leaf blight in Gangetic plains of West Bengal
}

\author{
SUNITA MAHAPATRA* and SRIKANTA DAS \\ Department of Plant Pathology, Bidhan Chandra Krishi Viswavidyalaya, Mohanpur 741 252, West Bengal, India
}

Received: 26 April 2017/ Accepted: 6 June 2017/ Published online: 24 July 2017

(C) Indian Phytopathological Society 2017

\begin{abstract}
Alternaria leaf blight of mustard caused by Alternaria brassicae and Alternaria brassicicola occur severely in different districts of West Bengal. A mustard variety 'Binoy' was used to assess the effect of iprodion. Three sprays of iprodion @ $0.2 \%$ at 10 days interval beginning from 45 days after sowing resulted in lowest Alternaria blight under moderate disease pressure and four sprays for high disease pressure resulted in highest seed yield and cost benefit ratio of 5.19 and 4.61, respectively for commercial seed and 8.43 and 7.48 for certified seed. Highest avoidable losses of seed yield and 1000 seed weight due to the Alternaria blight infection were $27.24 \%$ and $5.98 \%$ for three sprays and $30.71 \%$ and $0.74 \%$ for four sprays respectively. The results indicated that three sprays of Iprodion $(0.2 \%)$ resulted in minimum disease severity and maximum profit whereas under high disease pressure four sprays were essential for minimum disease severity and maximum profit in West Bengal.
\end{abstract}

Keywords: Alternaria leaf blight, avoidable yield loss, mustard, spraying, yield loss

Mustard [Brassica juncea (L.) Czern and Coss.] is an important oilseed crop in India, occupying about 6.32 million ha with the production of about 6.12 million tonnes. India's share in the world area is $25.6 \%$, but it contributes only $14.7 \%$ of world's production. The crop is also the major sources of income especially for marginal and small farmers in rainfed areas and resource-scarce region of the country. Mustard plays a pivotal role in the agricultural economy in India next to groundnut. Production of this crop, however, is reduced due to number of foliar diseases of which Alternaria blight caused by Alternaria brassicae and Alternaria brassicicola. The relationship between disease severity and seed yield and 1000 seed weight showed that the attainable yield was $1963.3 \mathrm{~kg} \mathrm{ha}^{-1}$ and 1000 seed weight $4.33 \mathrm{~g}$. and a drop of $12.78 \mathrm{~kg} \mathrm{ha}^{-1}$ and $0.082 \mathrm{~g}$, respectively for every one percent unit increase in disease severity (Mahapatra and Das, 2016b). However exact information on the extent of losses caused by different levels of Alternaria blight infection in this region is not known. The present study was undertaken to estimate the losses in the field under different levels of disease severity in the susceptible variety binoy and number of sprays of iprodion required to make different level of inoculum pressure of Alternaria blight pathogen.

\section{MATERIAL AND METHODS}

Field experiments were conducted at University Instructional farm, Jaguli, Mohanpur, during 2010-11 and

${ }^{*}$ Corresponding author: sunitamahapatra@yahoo.co.in
2011-12. The susceptible Binoy variety was sown on $15^{\text {th }}$ October in each year in $5 \times 5 \mathrm{~m}^{2}$ plots keeping a spacing of $30 \times 15 \mathrm{~cm}$ row to row and plant to plant in a randomized block design with three replications. All the recommended practices for tillage, irrigation and manuring with $80 \mathrm{~N}: 40 \mathrm{P}: 40 \mathrm{~K} \mathrm{kgha}^{-1}$ was followed. Five number of sprayings of fungicide $(0.20 \%$ a.i. $)$ as treatments were kept beside a treatment with unsprayed control. The sprays were started from 45 days after sowing irrespective of disease appearance due to the assumed severe incidence of the disease every year. The details of the treatments were $\mathrm{T}_{-1}=$ one spray (at 45 days after sowing); $T_{2}=$ two sprays (at 45 and 55 DAS); $\mathrm{T}_{3}=$ three sprays at 45,55 and $65 \mathrm{DAS} . \mathrm{T}_{4}=$ four sprays at (45, 55, 65 and 75 DAS); $T_{5}=$ (At 45, 55, 65, 75 and $85 \mathrm{DAS}$ ) $; \mathrm{T}_{6}=$ No spray (without fungicide application).

The disease was recorded at different growth stages viz., 45, 55, 65, 75, 85 and 95 DAS. The intensity of the disease was recorded by scoring all the individual plants selected (10 plants per replication) at random in each treatment using 0-5 point scale (Sharma and Kolte, 1994). Further, the PDI was calculated with the above scales using the formula given by Wheeler (1969). There were total six observations of disease severity were recorded upto ten days before harvesting. Therefore able to use entire sets of data as the value of 0.001 by replacing the zero disease severity and the maximum was 1.0. Total six observation of PDI was taken to calculate the AUDPC by following the formula of Wilcoxon et al. (1975) as follows:

$A U D P C=\Sigma\left[\left(Y_{i+1}+y_{i}\right) / 2\left(X_{i+1}-X_{i}\right)\right]$ 
$Y_{i}=$ severity at $1^{\text {st }}$ observation,

$X_{i}=$ Time (days) at first observation

$\mathrm{N}=$ Total number of observation

Crop was harvested after maturity at 110 days after sowing. The number of the siliqua and seed yield of net plots $\left(\mathrm{kg} \mathrm{ha}^{-1}\right)$ and 1000 seed weight $(\mathrm{g})$ was recorded during harvest. Overall efficiency and economics of these treatments in managing this disease were worked out by comparing their mean disease severity as AUDPC, seed yield, additional net income and cost-benefit $(C: B)$ ratio. The avoidable yield loss (AYL) due to this disease was calculated using seed yield and 1000 seed weight data from the fungicidal spraying trials by using following formula:

Avoidable yield loss $=(\mathrm{YP}-\mathrm{YU}) / \mathrm{YP} \times 100$,

Where, YP = yield under protected condition, YU = yield under unprotected condition, Whereas for yield loss the following formula was used, Percent $(\%)$ yield loss $=\left(Y_{P}\right.$ $\left.-\mathrm{Yx}) / \mathrm{Y}_{\mathrm{P}}\right) \times 100, \mathrm{Y}_{\mathrm{P}}=$ Potential yield, $\mathrm{Y}_{\mathrm{x}}=$ yield when percent disease index is $x$, Benefit cost $(B: C)$ ratio was calculated using formula, $\mathrm{B}: \mathrm{C}$ ratio $=$ Additional income from protection/cost of protection.

\section{RESULTS AND DISCUSSION}

The results revealed (Table 1) that disease severity (AUDPC) was higher in control plots (No spray) as compared with fungicide sprayed plots in both the years. The difference in disease severity with number of application of fungicide was statistically significant. The similar trend was observed in both the years. In the year 2010-11, the reduction in the disease severity was to the extent of 80.29 percent when sprayed five times followed by four, while it was less in plots receiving one spray and two. In the year 2011-12, minimum disease severity (AUDPC) was noticed on the plots receiving five number of sprays statistically at par on four numbers and maximum was in one spray followed by two sprays and their difference was statistically significant. Similar observations were also recorded that maximum reduction in disease severity in plots receiving five sprays followed by 4 number of sprays and decreased in the reduction of number of sprays were in one spray and two sprays and so on (Table 1).
So fungicidal sprays can reduce the disease was recorded earlier in ALB on mustard (Ayub et al., 1996; Mahapatra and Das, 2013). The results of the experiment clearly indicate that four fungicidal sprays on the susceptible variety like Binoy is sufficient to reduce the disease levels. These findings are agreed with result of Patil (1997) that reduction in AUDPC values of rust of sunflower with increase in number of mancozeb sprays.

\section{Yield characters}

Fungicidal treatment significantly improved the yield characters like 1000 seed wt. and seed yield of mustard than the untreated control.

\section{0 seed weight}

Different number of fungicide sprays showed differences in 1000 seed weights over years and their differences were statistically significant. In both the year 2010-11 and 2011-12, maximum 1000 seed wt. was obtained from the plots sprayed with five ( $3.98 \mathrm{~g}$ and $4.03 \mathrm{~g}$ ), significantly at par with four ( $3.95 \mathrm{~g}$ and $4.87 \mathrm{~g}$ respectively) and significantly different in three $(3.78 \mathrm{~g}$ and $3.75 \mathrm{~g}$ respectively) which were correlated with lower disease severity (AUDPC) in these treatments. Minimum 1000 seed wt. was recorded in plots given only one spray $(2.99 \mathrm{~g}$ and $3.05 \mathrm{~g})$ followed by two sprays $(3.35 \mathrm{~g}$ and $3.39 \mathrm{~g}$ ) and their difference was statistically significant for both the two years.

Avoidable yield loss in comparison to untreated control (no spraying) showed that with increase the number of sprayings lower level of yield loss was avoided as number of spraying of fungicides reduced the disease severity (AUDPC) of mustard. In 1000 seed wt. Maximum yield loss was avoided in the plots receiving five sprayings of fungicide which was similar on four sprayings but differ from three sprayings respectively for both the years. Minimum yield loss was avoided on one spraying followed by two sprayings in the year 2010-11 and 201112 respectively (Table 2 ).

The loss in 1000 seed weight over maximum number of sprayings (five sprays) in two different years showed different results. In both the year 2010-11 and 2011-12, maximum loss was obtained in untreated plots with no

Table 1. Disease severity of ALB in mustard in different spraying schedule during the year 2010-11 and 2011-12

\begin{tabular}{|c|c|c|c|c|c|c|}
\hline \multirow{2}{*}{$\begin{array}{l}\text { Number of Iprodione } \\
\text { sprays }\end{array}$} & \multicolumn{2}{|c|}{ AUDPC } & \multirow[t]{2}{*}{ Mean } & \multicolumn{2}{|c|}{ Percent reduction over control } & \multirow[t]{2}{*}{ Mean } \\
\hline & $2010-11$ & $2011-12$ & & $2010-11$ & $2011-12$ & \\
\hline $\mathrm{T}_{1}$ One spray & 41.5 & 40.0 & 40.75 & 23.52 & 23.52 & 23.52 \\
\hline $\mathrm{T}_{2}$ Two sprays & 30.33 & 33.17 & 31.75 & 44.68 & 36.70 & 40.69 \\
\hline $\mathrm{T}_{3}$ Three sprays & 22.13 & 22.67 & 22.40 & 59.21 & 56.40 & 57.80 \\
\hline $\mathrm{T}_{4}$ Four sprays & 13.57 & 11.03 & 12.30 & 75.08 & 78.76 & 76.92 \\
\hline $\mathrm{T}_{5}$ Five sprays & 10.68 & 9.33 & 10.00 & 80.29 & 82.03 & 81.16 \\
\hline $\mathrm{T}_{6}$ No spray & 54.83 & 52.36 & 53.59 & - & - & \\
\hline SEm \pm & 2.68 & 2.07 & 1.83 & & & \\
\hline CD at $5 \%$ & 5.96 & 4.62 & 4.07 & & & \\
\hline
\end{tabular}


Table 2. Loss assessment due to ALB on mustard in 1000 seed wt. for the year 2010-11 and 2011-12

\begin{tabular}{|c|c|c|c|c|c|c|c|c|c|}
\hline \multirow{2}{*}{$\begin{array}{l}\text { No. of } \\
\text { spraying }\end{array}$} & \multicolumn{2}{|c|}{1000 Seed wt. (g) } & \multirow{2}{*}{$\begin{array}{l}\text { Mean } \\
(\mathrm{g})\end{array}$} & \multicolumn{2}{|c|}{ Avoidable yield loss (\%) } & \multirow{2}{*}{$\begin{array}{c}\text { Mean } \\
(\%)\end{array}$} & \multicolumn{2}{|c|}{ Loss in 1000 seed wt. over $T_{5}(\%)$} & \multirow{2}{*}{$\begin{array}{c}\text { Mean } \\
(\%)\end{array}$} \\
\hline & $2010-11$ & $2011-12$ & & $2010-11$ & 2011-12 & & $2010-11$ & $2011-12$ & \\
\hline$\overline{T_{1}}$ & 2.99 & 3.05 & 3.02 & 4.56 & 5.99 & 5.27 & 24.87 & 24.32 & 24.59 \\
\hline $\mathrm{T}_{2}$ & 3.35 & 3.39 & 3.38 & 14.89 & 15.91 & 15.40 & 15.83 & 15.88 & 15.85 \\
\hline $\mathrm{T}_{3}$ & 3.78 & 3.75 & 3.77 & 24.53 & 23.54 & 24.03 & 5.02 & 6.95 & 5.98 \\
\hline $\mathrm{T}_{4}$ & 3.95 & 4.00 & 3.98 & 27.89 & 28.32 & 28.10 & 0.75 & 0.74 & 0.745 \\
\hline $\mathrm{T}_{5}$ & 3.98 & 4.03 & 4.02 & 28.38 & 29.37 & 28.87 & 0.0 & 0.0 & 0.0 \\
\hline $\mathrm{T}_{6}$ & 2.83 & 2.90 & 2.86 & - & - & - & 28.89 & 28.04 & 28.46 \\
\hline$\overline{\mathrm{SEm}} \pm$ & 0.03 & 0.05 & 0.02 & - & - & - & - & - & - \\
\hline CD at $5 \%$ & 0.07 & 0.10 & 0.05 & - & - & - & - & - & - \\
\hline
\end{tabular}

$\mathrm{T}_{1}=$ One spray, $\mathrm{T}_{2}=$ Two sprays, $\mathrm{T}_{3}=$ Three sprays, $\mathrm{T}_{4}=$ Four sprays, $\mathrm{T}_{5}=$ Five sprays, $\mathrm{T}_{6}=$ No spray

Table 3. Loss assessment due to ALB on mustard in seed yield for the year 2010-11 and 2011-12

\begin{tabular}{|c|c|c|c|c|c|c|c|c|c|}
\hline \multirow{2}{*}{$\begin{array}{l}\text { No. of } \\
\text { spraying }\end{array}$} & \multicolumn{2}{|c|}{ Seed yield $\left(\mathrm{kgha}^{-1}\right)$} & \multirow{2}{*}{$\begin{array}{c}\text { Mean } \\
\left(\mathrm{kgha}^{-1}\right)\end{array}$} & \multicolumn{2}{|c|}{ Avoidable yield loss (\%) } & \multirow{2}{*}{$\begin{array}{c}\text { Mean } \\
(\%)\end{array}$} & \multicolumn{2}{|c|}{ Loss in seed yield over $\mathrm{T}_{5}(\%)$} & \multirow{2}{*}{$\begin{array}{c}\text { Mean } \\
(\%)\end{array}$} \\
\hline & $2010-11$ & $2011-12$ & & $2010-11$ & $2011-12$ & & $2010-11$ & $2011-12$ & \\
\hline $\mathrm{T}_{1}$ & 1365.0 & 1335.00 & 1350.00 & 17.29 & 14.53 & 15.91 & 17.41 & 18.71 & 18.06 \\
\hline $\mathrm{T}_{2}$ & 1521.33 & 1560.0 & 1540.67 & 19.81 & 18.27 & 19.04 & 14.82 & 14.99 & 14.90 \\
\hline $\mathrm{T}_{3}$ & 1698.0 & 1731.0 & 1714.50 & 28.15 & 26.34 & 27.24 & 4.93 & 5.67 & 5.30 \\
\hline $\mathrm{T}_{4}$ & 1775.67 & 1825.0 & 1800.33 & 31.29 & 30.13 & 30.71 & 0.58 & 0.54 & 0.56 \\
\hline $\mathrm{T}_{5}$ & 1786.0 & 1835.0 & 1810.50 & 31.69 & 30.51 & 31.10 & 0.0 & 0.0 & 0.0 \\
\hline $\mathrm{T}_{6}$ & 1220.0 & 1275.0 & 1247.5 & - & - & - & 31.69 & 30.52 & 31.10 \\
\hline SEm \pm & 2.15 & 11.12 & 5.96 & - & - & - & - & - & - \\
\hline CD at $5 \%$ & 4.79 & 24.77 & 13.27 & - & - & - & - & - & - \\
\hline
\end{tabular}

$T_{1}=$ One spray, $T_{2}=$ Two sprays, $T_{3}=$ Three sprays, $T_{4}=$ Four sprays, $T_{5}=$ Five sprays, $T_{6}=$ No spray

fungicidal spray, followed by one spraying, two sprayings and three sprayings. Minimum loss were obtained in the plots receiving four sprayings (Table 2).

So the results in 1000 seed weight showed that loss in 1000 seed weight over maximum number of sprayings was minimum from the plots receiving four or more sprays than the plots sprayed once and untreated control. Therefore, the results of two years of field studies proved that in susceptible variety (Binoy) four spraying of iprodione $(0.20 \%$ a.i.) are sufficient to manage the Alternaria pod blight and realize the maximum 1000 seed wt of mustard.

\section{Seed yield}

Spraying of fungicides was also resulted significantly increased the seed yield of mustard for both the years (2010-11 and 2011-12).

Maximum seed yields were obtained from the plots sprayed four and more times which were attributed to the lower disease severity (AUDPC) of alternaria pod blight in these treatments. In the year 2010-11 and 201112 significantly higher yields were recorded from plots receiving four or more sprays than the plots sprayed once or untreated control. Maximum yields were obtained on five sprays followed by four and three sprays and their differences were statistically significant. Minimum seed yield was observed in one spray followed by two sprays and their difference was statistically significant (Table 3).

The avoidable yield loss of seed yield in comparison to untreated control was different in two different years and in pooled mean. In both the years with increase in number of sprays, there was an decrease in avoidable yield loss of seed yield of mustard. In the year 2010-11 and 2011-12, maximum yield loss was avoided in the plots receiving five sprays similar with four sprays and differs on three sprays. Minimum yield loss was avoided on single spray followed by two sprays (Table 3 ).

The losses in seed yield over maximum number of sprayings (five) were different in two different years and also in pooled mean. In both years, the loss was maximum in untreated control (no fungicidal spray) and minimum in the plots receiving four number of sprays.

Therefore, the results of two years of field studies proved that in a susceptible variety (Binoy) four sprayings of iprodione $(0.2 \%)$ are sufficient to manage the leaf blight and pod blight of mustard and realize economic yields. These findings are in agreement with the reports of Singh and Singh (2004) that 3 sprayings of mancozeb $75 \%$ WP $(0.25 \%)$ were most economical in managing the ALB on linseed on susceptible variety like Chambal and mustard (Mahapatra and Das, 2016a). These findings are also similar to those by Amaresh and Nargund (2004) that AUDPC values of alternaria leaf blight and rust of 
Table 4. Avoidable yield loss net return and benefit cost ratio of different spray schedule of Iprodione in "Binoy" mustard (Pooled data for 2010-11 and 2011-12)

\begin{tabular}{|c|c|c|c|c|c|c|c|c|c|}
\hline \multirow{2}{*}{$\begin{array}{l}\text { Number of } \\
\text { sprayings }\end{array}$} & \multirow{2}{*}{$\begin{array}{c}\text { Yield } \\
\left(\mathrm{kgha}^{-1}\right)\end{array}$} & \multirow{2}{*}{$\begin{array}{c}\text { Avoidable } \\
\text { yield over } \\
\text { unprotected } \\
\text { plot }\left(\mathrm{kgha}^{-1}\right)\end{array}$} & \multicolumn{2}{|c|}{ Additional income (Rs. ha-1) } & \multirow{2}{*}{$\begin{array}{c}\text { Cost of } \\
\text { protection } \\
(\text { Rs. ha-1) }\end{array}$} & \multicolumn{2}{|c|}{ Net return (Rs. ha-1) } & \multicolumn{2}{|c|}{$\mathrm{B}: \mathrm{C}$ ratio } \\
\hline & & & Commercial & $\begin{array}{c}\text { Certified } \\
\text { seed }\end{array}$ & & Commercial & $\begin{array}{c}\text { Certified } \\
\text { seed }\end{array}$ & Commercial & $\begin{array}{r}\text { Certified } \\
\text { seed }\end{array}$ \\
\hline $\mathrm{T}_{1}$ & 1350.00 & 102.50 & 4100 & 6662.5 & 1200.00 & 2900 & 5462.5 & 2.43 & 4.55 \\
\hline $\mathrm{T}_{2}$ & 1540.67 & 293.17 & 11717 & 19056 & 2400.00 & 9327 & 16656 & 4.88 & 7.94 \\
\hline $\mathrm{T}_{3}$ & 1714.50 & 467.0 & 18680 & 30355 & 3600.00 & 15080 & 26755 & 5.19 & 8.43 \\
\hline $\mathrm{T}_{4}$ & 1800.33 & 552.83 & 22113 & 35934 & 4800.00 & 17313 & 31134 & 4.61 & 7.48 \\
\hline $\mathrm{T}_{5}$ & 1810.50 & 563.0 & 22520 & 36595 & 6000.00 & 16520 & 30595 & 3.75 & 6.09 \\
\hline $\mathrm{T}_{6}$ & 1247.50 & & & & & & & & \\
\hline
\end{tabular}

$T_{1}$ One spray, $T_{2}$ Two sprays, $T_{3}$ Three sprays, $T_{4}$ Four sprays, $T_{5}$ Five sprays, $T_{6}$ No spray

Cost of protection. Efficacy of sprayer, $5000 \mathrm{~m}^{2} /$ day; rent of sprayer, Rs. 50.00/day, labour charges Rs. 100.00/day, cost of fungicide (Iprodione) @ Rs. 300/kg. Price of mustard 4000/quintal and 6500/quintal, commercial and certified seed respectively.

sunflower were less in higher number of spray of chlorothalonil, but low for ALB by Iprodion treatment. The present study also emphasizes that the treatment cost involved in the use of fungicides must be taken into consideration while selecting the fungicides for the effective and economical control.

\section{Benefit cost ratio}

Higher benefits were recorded in treatments getting three iprodion $(0.2 \%)$ spraying. The cost-benefit ratios of different fungicidal sprayings were $2.43,4.88,5.19,4.61$ and 3.75 for commercial seeds and for certified seeds $4.55,7.94,8.43,7.48,6.09$ respectively (Table 4).

It may thus be inferred that three sprays iprodion $(0.2 \%)$ in mustard are essential to obtain maximum yield when disease pressure is moderate or less. Three or two sprays of iprodion $(0.2 \%)$ are enough to get maximum profit. Whereas, when disease pressure is very high four sprays of iprodion are necessary in the Indo-Gangetic plains of West Bengal.

\section{REFERENCES}

Amaresh YS and Nargund VB (2004). Assessment of yield losses due ALB and rust of sunflower. Mycol. Pl. Pathol. 34: 75-79.

Ayub A, Dey TK, Jahan M, Ahmed MU and Alam KB (1996). Foliar spray of fungicides for control Alternaria blight of mustard. Ann. Bangladesh Agric. 6: 47-50.
Mahapatra S and Das S (2013). Evaluation of fungicides and botanicals against Alternaria leaf blight of mustard. Indian J. Plant Prot. 41 61-65.

Mahapatra S and Das S (2015). Effect of sowing dates, varieties and weather factors on the occurrence and severity of Alternaria leaf blight and yield of Indian mustard. Afr. J. Agri. Res. 10: 579-587.

Mahapatra S and Das S (2016a). Spraying schedule of garlic bulb extract, mancozeb and salicyclic acid against Alternaria blight of mustard. Indian Phytopath. 69: 413416.

Mahapatra S and Das S (2016b). Linear regression model for assessing the yield loss of mustard due to Alternaria leaf blight disease. Indian Phytopath. 69: 57-60.

Patil PV (1997). Studies on sunflower rust caused by Puccinia helianthi Schw. Ph.D. Thesis, University of Agricultural Sciences, Dharwad, 238 pp.

Sharma SR and Kolte SJ (1994). Effect of soil applied NPK fertilizers on severity of black spot disease (Alternaria brassicae) and yield of oilseed rape. Plant Soil 167: 313320.

Singh RB and Singh RN (2004). Occurrence and management of Alternaria blight of linseed in eastern India. PI. Dis. Res. 19: $120-124$

Wheeler BE (1969). An Introduction to Plant Diseases. John Wiley and Sons Ltd., London, U.K.

Wilcoxson Roy D, Skovmand B and Atif AH (1975). Evaluation of wheat cultivars for ability to retard development of stem rust. Ann. Appl. Biol. 80: 275-281. 